\section{US panel rejects hiding source of allegations of misconduct}

\begin{abstract}
Washington. A US scientific advisory board has rejected proposed rules that would allow the government to keep secret files on a researcher, including testimony that could be used anonymously to support a finding of misconduct. At a meeting earlier this month, the Public Health Service (PHS) committee on scientific integrity voted to recommend that the PHS abandon its attempt to obtain an exemption to the law that allows individuals to see the contents of government files on them.

Under the proposed regulations, the $\mathrm{Na}$ tional Institutes of Health and other research agencies in the health service would be granted an exemption to the Privacy Act to withhold the identity of whistleblowers. The act is intended to give individuals access to their own government records to ensure that they are accurate. In its request of 12 June for an exemption, the health service claims that such exemptions are routinely
\end{abstract}

granted to agencies that conduct criminal investigations.

But Estelle Fishbein, general counsel for Johns Hopkins University and a member of the misconduct advisory committee, believes that the proposed exemptions could violate a researcher's civil rights. If the exemption were to be granted, she points out, government health agencies would be allowed to withhold the identity of any informer. "An informer motivated by base motives [would] be accorded virtual immunity although his actions may set in motion government accusations, investigations, and hearings which will disrupt the personal and professional life of the scientist for years," she wrote in a comment to NSF. The Federation of American Societies for Experimental Biology and leges also oppose the proposed exemption.

Lyle Bivens, policy director for the PHS Office of Research Integrity, says that it is the Association of American Medical Col-

\section{NSF, NIH differ on reporting conflicts}

Washington. Controversy is a staple of US regulation of science, and conflict of interest is no exception. The Public Health Service (PHS), for example, was forced to withdraw proposed regulations published a few years ago and is now ruminating on a new set. The same angry reaction from the community has now befallen the National Science Foundation (NSF) after the publication of its own proposed conflict-of-interest regulations earlier this year (see Nature 358, 700; 1992).

NSF received more than 70 negative responses to its request for comments; most focused on a proposed requirement that researchers disclose any potential financial conflicts to the agency when they apply for grants. In contrast to the NSF proposal, the current PHS draft regulations would require researchers to disclose their financial holdings only to their own institutions, which would then examine them for potential conflicts and certify to the federal agencies that none exists. Many of those writing to NSF were protesting against the fact that its proposed rules were different from the proposed PHS rules and would require additional paperwork.

Why not have the government speak with one voice? The answer is not reassuring NSF did not follow the PHS rules because PHS would not share its draft of proposed regulations. PHS cited the need for confidentiality, but the argument would have carried more weight if the document was not widely available: half the universities in the country had already obtained a copy, and the University of Michigan even prepared a point-by-point comparison of the two proposals.

Meanwhile, Congress is threatening to muddy the waters. Last week the House of Representative's committee on government operations released another report in its continuing series on "Is Science for Sale?". Although this report focuses on conflicts with foreign corporations, it also recommends that PHS should embrace the NSF model and that researchers should be required to disclose conflicts when applying for federal funds.

Other legislators intend to take matters into their own hands. Several representatives, including John Dingell (Democrat, Michigan), the chairman of the House Energy and Commerce Committee, want researchers to disclose any relevant financial holdings in papers or talks based on federally funded research. The legislation, to be included in the same reauthorization bill for the National Institutes of Health that contains language lifting the current ban on fetal-tissue research (see page 761), is expected to be introduced in January and could be law by the spring.

Christopher Anderson unlikely that his office will change its mind. He points out that the Privacy Act exemption applies only to the initial, investigative, portion of the federal misconduct process. Once evidence of misconduct is found, the case is transferred to a court-like proceeding under an administrative law judge, who decides if sanctions are appropriate. In that proceeding, researchers have the right to face their accusers and to see the evidence against them.

Bivens says that the Privacy Act exemption would be used only when the identity of the accuser does not affect the case, as in a situation involving plagiarized material. But if a case rests on the testimony of a specific person, says Bivens, PHS officials would probably not withhold the person's name.

There is no guarantee that PHS officials would follow these internal policies, but Bivens argues that the risk of harm is slight given the different rules governing the administrative court proceeding. There is, however, one loophole: after an investigation finds evidence of misconduct and before the administrative court completes its proceedings, an accused scientist's name is put on a government list of scientists who are under investigation and should not be given grants. Although this is not considered a formal sanction, most scientists see it as a harsh penalty. If the health service is granted an exemption to the Privacy Act, researchers may soon find themselves on that list without knowing who put them there.

Christopher Anderson

\section{Cold fusion produces heat but no papers}

Tokyo. Advocates of cold fusion seem again to have forgotten the most elementary rule of scientific communication - publication. Last week, Japanese researchers at Nippon Telegraph and Telephone Corporation (NTT) generated tremendous heat among the country's media by announcing at a conference in Nagoya that they had found "undoubted direct evidence of cold fusion".

The statement is not new in the threeand-a-half-year history of the phenomenon. But, as has often been the case for supporters of a process claimed to have been discovered by chemists Stanley Pons and Martin Fleischmann, the NTT researchers have no paper, published or submitted, to back up their claim. The company's public relations department could not even provide an abstract for the announcement.

NTT scientists say that they have detected helium-4 from palladium electrodes soaked in deuterium gas and then heated in a vacuum. David Williams of University College, London, says that he is "underwhelmed" by their evidence and that similar findings have been traced to contamination from the atmosphere.

David Swinbanks 